\title{
Reflecting the Ancient Administrative Tendencies of the Oyo Kingdom in Modern Local Government System
}

\author{
Oluwadare Ayeni \\ Department of Public Administration, Obafemi Awolowo University, Ile-Ife, Nigeria
}

Email address:

oluwadareayeni.oauife@gmail.com, ooayeni@oauife.edu.ng

\section{To cite this article:}

Oluwadare Ayeni. Reflecting the Ancient Administrative Tendencies of the Oyo Kingdom in Modern Local Government System. Journal of Public Policy and Administration. Vol. 5, No. 2, 2021, pp. 30-36. doi: 10.11648/j.jppa.20210502.11

Received: March 30, 2021; Accepted: April 19, 2021; Published: April 29, 2021

\begin{abstract}
Globally, the debate on the adaptability of traditional institutions into local governance is ongoing. A school of thought believes that traditional institutions foster local government administration especially in mobilizing grassroots support through its traditional strategies. Another school characterized administrative practices of traditional institutions as anachronistic and undemocratic. While synergy among these views is desirable, this study investigates the extent to which tendencies of traditional institutions are reflected in the modernised local government administration. Respondents were selected from Atiba Local Government Council, the Community Leaders, and the Ministry of Local Government and Chieftaincy Matters in Oyo State with a total population (304) and sample size (152). Primary and secondary sources were employed for data collection. The study revealed traditional institutions partake in security administration (80.6\%) and information management $(84.4 \%)$ but not so active in project monitoring $(93.3 \%)$, on overall the study reported that roles allotted traditional institutions were not statistically significant, $c 2(6,670)=0.414, p>0.05$. The study further established that effects of the traditional institution are more prominent in; effective two-way communication between the grassroots and local government $(89.5 \%)$, promotion of peace and order $(93.3 \%)$ but less prominent in collaborative governance $(91.1 \%)$, it was revealed that effect of traditional institutions on local governance is not statistically significant, $\mathrm{c} 2(6,670)=0.007, \mathrm{p}>0.05$. For the tendencies of traditional institutions to be harmoniously reflected in the local government administration, institutional and constitutional reforms are hereby recommended.
\end{abstract}

Keywords: Tradition, Local Governance, Kingdom

\section{Introduction}

Evidence of plurality and diversity in the pre-colonial Africa cultures and local governance structures are well documented in the literature. In the view of Kalilu (2013), organised empires and kingdoms with sophisticated traditional institutions existed in Africa before the wave of European imperialism took its tolls. These kingdoms were regional and political strongholds as well as harbingers of Africa civilization [16]. Africa's civilization cut across different cultures and traditions. The traditional institutions of local governance and administration of the Africa kingdoms provided platforms upon which their subjects were governed. These antediluvian empires and kingdoms were known for the level of sophistication in their administrative machinery.

According to to Davidson, B. and Buah, F. K. (1977), these kingdoms spread far and wide across the Africa continent at a time in history [8]. In Northern Africa, historical accounts enlisted empires like the Egyptian Empire (3150-30BCE), Carthaginian Empire (650-146BCE), and Kingdom of Kush (1070-350BCE) (Glenn, 2000; Edward, 2004; Ramsey et al., 2010). Among the prominent kingdoms in Eastern Africa were the Kingdom of Punt (24001069BCE), Aksumite Empire (50-937CE), and the Ethiopia Empire (1137-1974CE) (Shaw \& Nicholson, 1995; Burstein, 2009; Kenny, 1968). Mali Empire (1235-1600CE), Songhai Empire (1464-1591CE), Oyo Empire (1400-1895CE), and Asante Union (1701-1894CE) were pronounced in the western coast of Africa (Collins \& Burns, 2007; Oliver and Atmore, 2001; Davidson, 1977), and Kongo was a notable kingdom in Central Africa (Thornton, 1977).

According to Davidson, the local administrative structure of the Kingdoms was already established. For instance, the 
Mali Empire practiced a centralised system of administration, the Kings governed the entire provinces through representatives (i.e the governors). There were a wellestablished tax system and several ministries, such as the Ministry of Agriculture, Ministry of Finance and Military of Defence [8]. Authors like Fortes, M. and Evans-Pritchard, E. E. (1940 and Nadel, S. F. (1942) broadly established two types of pre-colonial African political systems. One, a system characterised by centralised authority, administrative machinery, and justice institutions. The other, a system defined by segmented structures with less powerful central authority as well as adept divisions in social class $[12,18]$. For Nadel, commonality in the pre-colonial African political system rest on a scheme background of territorial sovereignty, centralised government specialised administrative staff, and state monopoly of the use of force.

Although, Vansina's 1962 classification of administrative and political structures in the pre-colonial African states largely implied general conscription of extremely centralised and dictatorial peculiarities in the way and manner the precolonial African states administered their subjects. Some reflected more greatly, tendencies of the modern-day confederation, federation, and democracy in their governance architecture [24, 8]. The Ashati Union, the Igbo Conglomerate and the Oyo Empire among others made remarkable inscriptions of modern democratic features in their system of government $[25,8,13]$.

The Oyo Empire now Oyo State in the western region of Nigerian was prominent among the pre-colonial West Africa Kingdoms for the level of sophistication which characterised her political and administrative systems [13, 8]. Administration of the Old Oyo Empire reflected political and administrative variables of modern democracy. For instance, the Oyo Empire operated a confederated state by giving town autonomy to govern themselves with a high degree of sophistication in local administration built on well-structured traditional political institutions. Also, the Old Oyo Empire was notable among other empires in the pre-colonial Western African for the deployment of check and balance, and a seven-man legislature chamber (the Oyomesi) which checkmated activities of the king, equivalent of modern-day America's Congress.

In the contemporary international system, most nations strive to adopt democracy as their official form of government. In Nigeria, one of the reasons for the inability to achieve sustainable democracy, easy administration and development is the failure to harness the traditional political institutions. The critical roles the traditional institutions could play in local government administration have not only been unacknowledged but have also been grossly underestimated by their relegation to the background [10]. The 1989 and 1999 constitutions of the Federal Republic of Nigeria did not ascribe any specific political or administrative function to the traditional institution that once controlled various aspects of administration in the country [23]. This paper builds its searchlight by examining reflects of administrative peculiarities of the Oyo Empire in the modern local government system in Nigeria.

\subsection{Objective and Hypotheses}

As a descriptive study, this paper probes the role and effects of traditional institutions in the administration of local government. It further establishes challenges affecting the performance of traditional institutions in the administration of governance at the grassroots. The following research hypotheses are formulated:

H0: There are no significant roles allotted to traditional institutions in the administration of local governance in Nigeria

H0: Traditional institution exert no significant effect on local governance in Nigeria

\subsection{Traditional Institutions and Local Governance in Postcolonial Africa}

It has been established that the traditional institution was the major instrument of governance before the arrival of imperialism in Africa. Local governance and administration were often associated with the custodians of traditional institutions at the instance of religion, legislative, executive and judicial functions $[4,6,25]$.

The relegation of traditional institutions in the modern local administrative system, a position that is held for a long period as a new version of decentralization has eroded the tradition and commonalities that African societies are known for overtime. This has brought a disconnect between the government and the people. Another factor that contributed to the obliviousness of traditional institutions in the scheme of the local administrative system in Nigeria was the 1976 Local Government Reform [23]. The eventual fall out of this arrangement subjected traditional institutions to the wimps and caprices of state government. The custodian of traditional institutions, that is the traditional rulers, often suffered in the hands of the state government in terms of a salary cut, salary stoppage, restriction, suspension, banishment, dethronement and others [3].

On the contrary, Sokoh argued that traditional institutions are still relevant in the local administrative system but hope to get constitutional recognition. He stresses the relevance of these institutions in matters relating to elections and national issues. Political aspirants and echelon officers of public institutions visit traditional rulers to legitimise and establish their reign among the grassroots [23]. For, Emordi, and. Osiki, traditional institutions are still the closest local governance apparatus to the grassroots, and at the same, serve as mobilisation buffer for grassroots politics. Traditional rulers are still vital to the attainment of economic progress and political stability at the local level. The continued relevance of traditional authorities to the local government system in contemporary [10].

Nigeria political and security challenges as Egwurube rightly noted may be attributed to the following reasons. These include the dormant nature of the political culture of the grassroots, local legitimacy enjoyed by the traditional 
institutions, and the need to find a replacement for the troubled modern local administration [9]. Traditional institutions, although, lost part of their roles, yet still active in some areas of local governance. The modern local administration is aided by the traditional institutions in the area of community policing, grassroots mobilization, settlement of communal conflicts and others.

Fatile and Adejowon, averred the three premises why traditions are still more relevant in the helm of affairs. First, the traditional institutions still enjoy strong loyalty from the local chiefs. Also, the local handlers of these institutions are experienced in dealing with local affairs. Third is that traditional institutions still enjoy strong loyalty from the local chiefs and lastly, the local institution provides an alternative platform for settling local conflict and agreement $[11,15]$. In the realm of policy formulation, local institutions till today provide cultural implications of any proposed policy on local subjects. This is because the traditional institution provides a strong linkage between the government and the grassroots.

Although, the powers enjoyed by the traditional institutions have been watered down by the reality of the modern local administrative system. Yet, they still command legitimacy, loyalty, and respect from the local subjects and handlers of the modern administrative apparatus.

\subsection{The Roles of Traditional Institutions and Nation Building}

The application of traditional institutions in national building cut across various aspects of national development. Traditional institutions after the emergence of democratic governance have demonstrated tendencies to easily adapt to democratic rules, norms, practices, and teaching (Oomen, 2002). This made traditional institutions to be fundamentally positioned in politics and governance especially at the grassroots.

Expanse literature provides evidential support on the involvement of traditional institutions in nation-building. As the closest level of administration to the grassroots, the traditional administrative system provides a veritable platform upon which both human and material resources could be harnessed for development purposes. In the view of Abdullahi, traditional institutions contribute enormously to the administration of security in Nigeria [1]. This according to Abdullahi is not unconnected with the locality of modus operation of these traditional institutions. They enhance the administration of security by providing local surveillance and maintenance, making intelligence reports available to security agencies, coordinating a vigilante system. The traditional rulers can carry out these complementary roles with the instrumentality of a well-designed traditional institution system [2].

Oyewo, affirmed the strategic position traditional institution occupied in the socio-political development of the Nigerian nation. These institutions complement the effort of the local council in enforcing local laws. He stressed that traditional institutions are apt in carrying out effective communication at the local level [21]. Similarly, traditional institutions, according to Bello-Imam complement efforts of government at the Federal, State and local levels in mobilising citizens for developmental activities that require collective effort and understanding of the locals [5]. This implies that through traditional institutions, the implementation of government policies and decisions are decentralised to achieve the maximum result.

Mojelafa, a South African author stressed that the traditional institution is part of core African democracy. When it comes to cultural and customary practices, the traditional institution is better placed to manage any governance issues arising from culture and customs [17], to him traditional local governance is based on strong traditional institutions. More same Crook reviewed that traditional institution technicalities are still being deployed in the management and control of land tenure in some African countries. It was reported that the practice of traditional landholding for commercial and farming purposes constituted another contribution of traditional institutions [7].

As part of its quota to nation-building, cultural leadership, mobilization for political participation and support and commitment to achieving peace and unity at the grassroots are provided instrumentality of traditional institutions [7]. Tonwe and Osemmola wrote more community on the economic importance of the traditional institution in grassroots development. Since the goal of a modernized local government system is to deepen economic development and wealth creation as the grassroots, adapting traditional institutions toward this end posits a greater opportunity to attain grassroots development as well as create a convincing path for the local communities to access public service deliverables [24]. The argument is that tapping into the opportunities of traditional institutions while considering policy options for grassroots governance and development tends to correlate with an all-encompassing national development.

Similarly, Osakede and Ijimakinwa, expressed the role of traditional institutions in today's local administration to include supporting government efforts in revenue generation and resource mobilization of though the traditional institution, supportive services such as sensitization of the grassroots on immunization programme, and voter registration [19]. Traditional institutions occupied a very important sport in peacebuilding. As the reservoir of customs and traditions, traditional institutions provided a workable socio-political structure for maintaining peace and bonds among local communities, as such represent agents of social equilibrium and nation-building. Given the above, providing answers to the questions of whether traditional institutions aid nationbuilding seems not difficult. Literature relegated the school of thought that traditional institutions are primitive and do not fit in the new democratic order.

It appears that traditional institutions are generally granted regulated roles in contributing to grassroots development. This is because, despite lack of stationary recognition of their institution, they still perform functions in areas such as security administration, conflict resolution, and 
peacebuilding, political and economic mobilization and land administration [7, 24, 19, 17]. With all these, the traditional institution provides a veritable stand upon which the local energetic masses can be drafted into the developmental philosophy of nation-building.

\section{Methodological Analysis}

The study design was descriptive. It examined the relevancies and relationship of traditional institutions in local government administration in Atiba Local Government of Oyo state. Popoola and Magidimisha opined that Oyo State was created out of the old western region of Nigeria. Oyo State has 33 local government councils. Atiba local government is one of the 33 local governments of the state. Atiba local government area of Oyo state has its headquarters in the town of Ofa Mefa. Atiba local government has 10 wards for political purposes. It has a land area of a 219.753kilometer square [22]. Primary and secondary data were employed. The primary data soured through a survey conducted using the questionnaire as the instrument, and secondary data soured from government documents, journal articles, and internet sources.

Although the 2006 population census estimated 169,702 persons in Atiba Local Government Council Area, the study was based on specific information about local governance, multi-stage sampling to select the targeted population for this study. The purposive selection was used to the Senior Staff of Atiba Local Government Council with 242 members, the Community Leaders from the ten (10) wards of the Local Government, Staff of Oyo State Ministry of Local Government and Chieftaincy Matters with 52 members, making a total of 304 participants. Random sampling was used in selecting fifty percent (50\%): i.e. twenty-six (26) of the staff of the Ministry; 121 members of the Senior Staff of Atiba Local Government and five (5) Community Leaders to make a sample of 152 participants. The questionnaire contained close-ended questions structured in such a manner as to make respondents answer the question by ticking any of the options provided. It was simply designed and structured, thus: SA - Strongly Agree; A - Agree; SD - Strongly Disagree; D - Disagree. In summary, the responses were categorized into Agreement (\%) and Disagreement (\%) to make inferences about each of the items raised in the research instrument. For instance, if the aggregate of Agreement (AGR. in \%) is greater than the aggregate of Disagreement (DGR. in \%), we report the item as an outcome, and if otherwise, we report the item as not an outcome. The study achieved a response rate of $88 \%$. Simple percentages and chi-square were used to analyze the data. Chi-square was computed on respondents' views on the roles and effects of traditional institutions measured along with two categorical variables; study group (Ministry of Local Government Affairs, Council Government, and Community Leaders); opinion (Strongly Agree, Agree, Disagree and Strongly Disagree).

\section{Result Presentation and Analysis}

\subsection{Roles of Traditional Institution in Local Governance Administration}

The paper presents information on roles played by traditional institutions in local governance. The decision set was that at the instance of more agreement against less disagreement about any assertion, such assertion becomes the survey's outcome. On security administration, analysis shows that traditional institutions complement the effort of the local council in community policing and neighborhood watch with a support rate of $80.6 \%$ against a $19.4 \%$ rejection rate. This result portrays that in contemporary local governance, there are high tendencies that the old traditions and tactics of traditional institutions still dictate local policing in the state. Similarly, $67.9 \%$ of the responses indicated that the conflict resolution mechanism of the local government has some semblance of traditional origin. This implies that traditional institution's resolution strategies are reflected in the local administrative system in the state.

The result of the study further identified the information management role of traditional institutions. $84.4 \%$ of the respondents supported the research assertion that the role of traditional institutions in ensuring adequate management of information at the grassroots is recognized by the council. In the area of project monitoring, respondents claimed that they do not monitor development projects initiated by the council. This outcome was supported by $74.6 \%$ of the responses. The result was affirmatively positive on the view that traditional institutions complement the local administrative system in mobilizing local people for grassroots politics and development. This outcome was ascertained by a support rate of $93.3 \%$. The result of the hypothesis tested indicated that roles allotted to traditional institutions in the administration of local governance in Nigeria are not statistically significant, c2 $(6,670)=0.414, \mathrm{p}>0.05$.

\subsection{Effects of Traditional Institutions in the Administration of Local Government}

The effects of traditional institutions on the administration of local government were tested among selected respondents in table 1 . The results show that some level of peace and order sustained at the local government can be linked to the role played by the traditional institutions. This result was claimed by the majority of the respondents with $93.39 \%$ on aggregate. In a different pattern, $85 \%$ as against $14.9 \%$ of the respondents rejected the claim that the existence of traditional institutions side by side with the local administrative system has strengthened democratic ideology among the locals. $89.5 \%$ of the respondents agreed that through the traditional institution, effective communication, especially between the people and $91.1 \%$ of the responses, indicated that the majority of the respondents behave that the cost incurable by the council government has been minimized through adoption of traditional institution's conflict control mechanisms. $80.5 \%$ of the responses 
indicated many of the respondents do not share the view that collaboration for development exists between the traditional institution apparatus and modern-day local government system. This implies that there is no concrete synergy between the two systems of governance. Confirmatory test shows that traditional institution exert no significant effect on local governance in Nigeria, c2 $(6,670)=0.007, \mathrm{p}>0.05$.

\subsection{Challenges of Traditional Institutions in Local Governance}

From table 2, the study identified the advisory role of traditional leaders $(82 . \%)$, constitutional arrangement $(77.7 \%)$ interference of state government $(77.6 \%)$, and institutional arrangement $(91.1 \%)$ as the prominent factors undermining the reflection of tendencies of traditional institutions in the modern local government administrative system. Factors such as the education level of traditional rulers $(75.0 \%)$ and illiteracy level of the local populace $(81.4 \%)$ were not affirmed by the respondents to undermine the efforts to bring the realities of administrative tendencies of the traditional institution into the contemporary local government administration in Nigeria.

Table 1. Roles and Effects of Traditional Institution in Local Governance.

\begin{tabular}{|c|c|c|c|c|c|c|c|c|c|c|}
\hline \multirow{3}{*}{ ITEMS } & \multicolumn{5}{|c|}{ Agreement } & \multicolumn{5}{|c|}{ Disagreement } \\
\hline & \multicolumn{2}{|c|}{ SA } & \multicolumn{2}{|l|}{$\mathbf{A}$} & \multirow{2}{*}{$\sum(\%)$} & \multicolumn{2}{|l|}{$\mathbf{D}$} & \multicolumn{2}{|c|}{ SD } & \multirow{2}{*}{$\sum(\%)$} \\
\hline & $f$ & $\%$ & $f$ & $\%$ & & $f$ & $\%$ & $f$ & $\%$ & \\
\hline \multicolumn{11}{|l|}{ Roles of Traditional Institution in Local Governance } \\
\hline $\begin{array}{l}\text { Traditional institutions are involved in community policing and neighborhood watch } \\
\text { within the council area. }\end{array}$ & 82 & 61.2 & 26 & 19.4 & 80.6 & 17 & 12.7 & 9 & 6.7 & 19.4 \\
\hline Traditional institutions provide alternative resolution platforms. & 70 & 52.2 & 21 & 15.7 & 67.9 & 30 & 22.4 & 13 & 9.7 & 32.1 \\
\hline The role of traditional institutions in information management is recognized by the council. & 75 & 56.0 & 38 & 28.4 & 84.4 & 11 & 8.2 & 10 & 7.5 & 15.7 \\
\hline Traditional institutions help in monitoring developmental projects by the local council. & 16 & 11.9 & 18 & 13.4 & 25.3 & 65 & 48.5 & 35 & 26.1 & 74.6 \\
\hline $\begin{array}{l}\text { One of the roles performed by traditional rulers is mobilisation of grassroots for } \\
\text { political matters. }\end{array}$ & 85 & 63.9 & 40 & 29.9 & 93.3 & 2 & 1.5 & 7 & 5.2 & 6.7 \\
\hline \multicolumn{11}{|l|}{ Effects of Traditional Institution on Local Governance } \\
\hline Traditional institutions aided the promotion of peace and order within the council. & 65 & 48.5 & 60 & 44.8 & 93.3 & 7 & 5.2 & 2 & 1.5 & 6.7 \\
\hline $\begin{array}{l}\text { Democracy is strengthened at the grassroots as a result of massive mobilisation by the } \\
\text { traditional leaders. }\end{array}$ & 6 & 4.5 & 14 & 10.4 & 14.9 & 55 & 41.0 & 59 & 44.0 & 85.0 \\
\hline $\begin{array}{l}\text { Through the instrumentality of traditional institutions, effective two-way } \\
\text { communication is achieved between the local government and the people. }\end{array}$ & 59 & 44.0 & 61 & 45.5 & 89.5 & 5 & 3.7 & 9 & 6.7 & 10.4 \\
\hline $\begin{array}{l}\text { The cost of settling conflicts by the local council has been minimised through the } \\
\text { adoption of traditional institution's mechanisms. }\end{array}$ & 58 & 43.3 & 64 & 47.8 & 91.1 & 10 & 7.5 & 2 & 1.5 & 9.0 \\
\hline $\begin{array}{l}\text { Collaboration between local government councils and traditional institutions aids the } \\
\text { delivery of developmental projects. }\end{array}$ & 3 & 2.2 & 23 & 17.2 & 19.4 & 81 & 60.4 & 27 & 20.1 & 80.5 \\
\hline
\end{tabular}

Source: Fieldwork, 2020

Table 2. Challenges Affecting Traditional Institutions in the Administration of Local Governance.

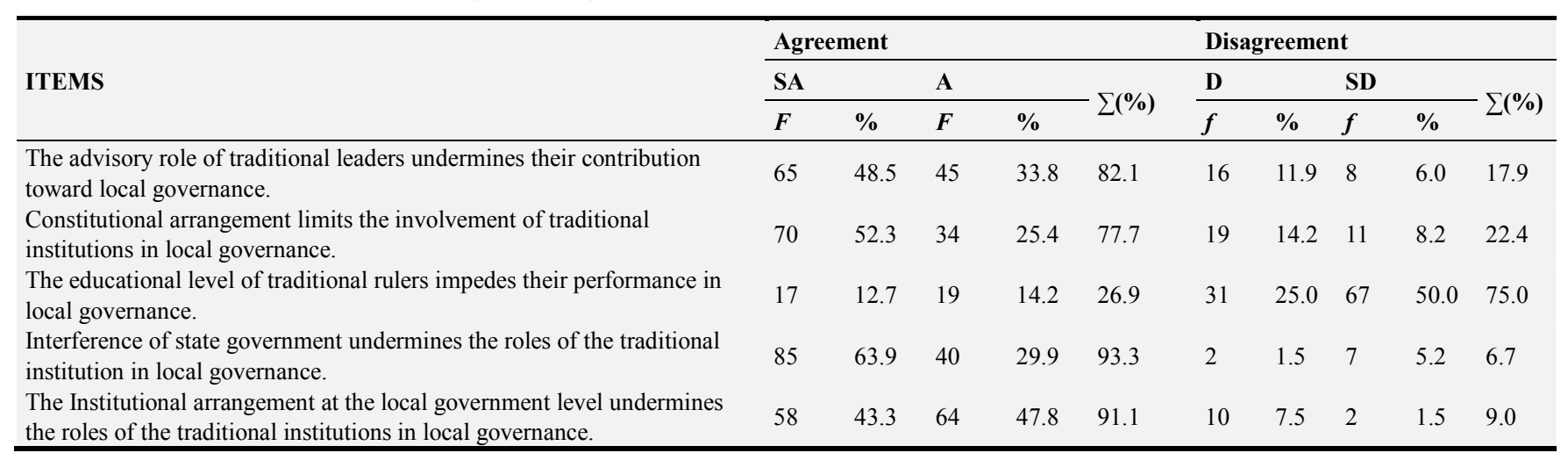

Source: Fieldwork, 2020

Table 3. Hypotheses Testing@5\% Level of Significant.

\begin{tabular}{|c|c|c|c|c|}
\hline Statements of Claim & $\mathbf{N}$ & df & $\chi^{2}$ & Sig. \\
\hline $\mathrm{H}_{0}$ : There are no significant roles allotted to traditional institutions in the administration of local governance in Nigeria & 670 & 6 & 0.414 & 0.999 \\
\hline $\mathrm{H}_{0}$ : Traditional institution exert no significant effect on local governance in Nigeria & 670 & 6 & 0.007 & 1.000 \\
\hline
\end{tabular}




\section{Results Analysis}

Despite inadequacy in the adoption of traditional institutions into the modern local administrative system, they still aid local security administration. This is not unconnected with the level of acceptance of traditional institutions as the primary custodians of local traditions among the local subjects. These institutions complement modern institutions in the area of community policing and neighborhood watch. ${ }^{1}$ and ${ }^{2}$ established that the localization embedded in the mode of operation of traditional institutions correlates their effort in maintaining peace and order in the local communities. The result indicated that the traditional administration structure can be positively harnessed in conflict management. Using conflict resolution mechanism of traditional origin provide a formidable alternative to settling the conflict. This will aid the effectiveness of the modern means of resolving conflict by the local government administration and practices. This finding corroborates the views of Oyewo and Maddick, who both established that traditional institutions are well-positioned in managing local conflict giving the level of legitimacy and respect to the local subject response in the institutions $[21,15]$.

It was discovered that through the traditional apparatus of local institutions, effective communication is established between the local subjects and local government on one hand, and between the local populace and another level of government other than local government. This role, as performed by the traditional institution will aid communication of government policies and actions on public issues to the public [21]. The role of the traditional institution in the monitoring of development projects appears vague. This, of course, can be attributed to a lack of constitutional backings. The traditional rulers' objections to the abandonment of public projects exert no significant response from the government. This makes the traditional institutions appear to be a dog without teeth. This result negated the submission of Tonwe and Osemwota that the traditional institution as the engine room of grassroots development [24]. Mobilisation of local resources and materials is often limited to the third tier of government, the result indicated that traditional institution performs a corollary role to local government in mobilising local subjects. Tonwe and Osemwota, Osakede, K. O. and Ijimakinwa, and Crook converged on the suitability and productivity of employing traditional institutions in mobilising local subjects for political and activities [24, 19, 7].

The study further revealed that the effect of the traditional institution in the strengthening of local democracy was not prominent. This is not in conformity with the position that traditional institution promotes democratic tendencies among the local populace by mobilising the local subjects for participating in grassroots politics $[10,22]$. It could be said that traditional authorities contribute greatly in mobilising the grassroots populace to participate in government activities such as health immunization programme, environmental sanitation, political activities and so on, but the level of commitment differs across the traditional institution. Despite this, Sokoh, Ubink, Emordi and Osiki submission might be based on different peculiarities of traditional institutions other than the traditional authorities proximate to the study location. Furthermore, the study reaffirmed the significance of traditional authorities in maintaining peace and order in society. This indicates that a more secure and protected local environment is possible if the potentials of the security apparatus of traditional institutions are optimally synchronised with the local administrative system. Oyewo and AbdulQadir maintain a similar position on the usefulness of traditional institutions in law enforcement and security administration at the grassroots $[21,2]$.

The study identified the advisory role allotted to the traditional institutions in local governance as a predicament limiting their involvement in local government administration. This relegation came after the local government reform of 1976 which was aimed at giving more autonomy to the local government without reference to the significance of the roles played by traditional institutions in local governance [20, 23]. The gradual erosion of the constitutional role of traditional institutions aided in dwindling and fading in their contribution toward grassroots development. The aftermath effect of this is that the formal structure of local administration is design independently of existing traditional authority. The constitution of the Federal Republic of Nigeria as amended has empowered the state government to enthrone and dethrone traditioner rulers at will. A gesture that limits the exploration of historic potentials of traditional authorities in local government administration.

More importantly, state governments while exploiting the loopholes in the constitution carpeted independence of traditional institutions and local government (the purported autonomous tier of government aimed by previous local government reforms) especially within the ambiance of section 7 (1) of the 1999 constitution. Many stakeholders and traditional leaders have complained about the usurpation of both the roles of traditional rulers and local government as an institution. Similarly, the local government institution framework is structured against the effective contribution of local traditional authorities as local government councils are not sensitive to the advisory role given to these institutions.

\section{Conclusions and Recommendations}

Although, the traditional institution still co-exist along with the contemporary local government administrative system. The study submitted that the robust administrative propensities and tendencies that dominated local governance before the new order of government have not been fully explored and appreciated. The relevance of traditional institutions in local governance has been reduced to the selective and subjective interpretation of operators of modern machinery of governance. Given these remarks, appropriate suggestions were offered in the following paragraphs.

Local government systems and structures need institutional and administrative reforms that will catalyse traditional institutions 
into the core administration of local governance. Harmonisation of administrative tendencies of the traditional institution and the modern local government system will bring more development to the grassroots. Concerted efforts being made by the traditional rulers to mount pressure on the federal government and state government for amending the 1999 constitution to recognise traditional institutions as a coordinated third tier of government with constitutionally stipulated functions.

The federal government should be encouraged to scrap the Ministry of Local Government Affairs to block excessive interference from the state government. This extends to rearrangement in the salary administration of traditional rulers. The emolument of the traditional rulers should be the first-line charge in the Consolidated Revenue Fund of the federation. With this, the good old stories of the potency of traditional institutions can be replicated in pari pasu with that of contemporary local administration.

\section{References}

[1] Abdullahi, S. A. (2005), Youth Deviance and Traditional Authority in Kano Metropolitan: Some Issues in Chieftaincy and Security in Nigeria 40th Anniversary of the Emirship of HRH; Alhaji (Dr.), Ado Bayero.

[2] AbdulQadir, U. A., (2016). Traditional rulers and security administration in Nigeria: Challenges for the 21st century. Journal of Humanities and Social Science, 21 (8).

[3] Adesoji, A. O. (2010) Traditional Ruler Ship and Modern Governance in the 20th Century. In Babawale, T. A. Alao and A. Adesoji (Eds.), The Chieftaincy Institution in Nigeria, Lagos: Concept Publishers for Centre for Black and African Arts and Civilisation.

[4] Afigbo, A. E. (1972). The Warrant Chiefs. London: Longman Group Ltd.

[5] Bello-Imam, I. B. (1987). The Future of Local Government in Nigeria in Olugbemi, S. O. (ed), Alternative Political Futures for Nigeria, A Publication of the Nigerian Political Science Association.

[6] Cookey, S. J. S., Alemika, E., Amucheazi, E., Oyebode, A. B., and Yahaya, A. D. (2010). Traditional Rulers in Nigeria. Ibadan: Safari Books Ltd.

[7] Crook, R. (2005). The Role of Traditional Institutions in Political Change and Development. Ghana Center for Democratic Development.

[8] Davidson, B. and Buah, F. K. (1977). A History of West Africa 1000-1800. London: Longman Group Limited.

[9] Egwurube, J. (1985). Traditional Rulers and Local Government under the 1979 Nigerian Constitution, in Aborisade O. (ed) Local Government and the Traditional Rulers in Nigeria, Ile-Ife, University of Ife Press.

[10] Emordi, E. C. and. Osiki, O. M. (2008). The Traditional rule in Nigeria: The crisis of relevance in contemporary politics. Ife J. History, (4): 67-92.
[11] Fatile, J. O. and Adejowon, K. D. (2009). The Place of Traditional Rulers in Local Government Administration in the New Political Order in Nigeria. Africa Journal of Social Policy and Administration, 2 (1), 9-19.

[12] Fortes, M. and Evans-Pritchard, E. E. (1940). African Political Systems. London: Oxford University Press, pp. 1-23.

[13] Green, T. (2015). African Kingdoms: A Guide to the Kingdoms of Songhay, Kongo, Benin, Oyo, and Dahomey C. 1400-C. 1800. Oxford Cambridge and RSA Examinations, Version 1.

[14] Kalilu R. O (2013). Art from art for art: Conceptualising existence in the space of the visual arts (10th LAUTECH Inaugural Lecture Series), (Ogbomoso, Nigeria: Ladoke Akintonde University of Technology).

[15] Maddick, H. (1963) Democracy, Decentralization, and Development. London: Asia Publishing House.

[16] Melanie, D. T. (2018). 9 Ancient African Kingdoms You Should Know Anout. Rhino Africa. Available at https://blog.rhinoafrica.com/2018/03/27/9-ancient-africankingdoms.

[17] Mojalefa L. J. (2017). The Role and Significance of Traditional Leadership in the Governance of Modern Democratic South Africa, Africa Review.

[18] Nadel, S. F. (1942). A Black Byzantium, London, 1942, p. 69.

[19] Osakede, K. O. and Ijimakinwa, S. O. (2015). Traditional Institution and the Modern Day Administration of Nigeria: Issues and Prospects. Journal of Research and Development, 2 (9), 32-40.

[20] Oyediran, O. (2001). "Local Government as The Third Tier of Government in Nigeria: The 1976 Local Government Reforms and After", in Elaigwu, J. Isawa and Akindele, R. A. eds, Foundations of Nigerian Federalism, 1960-1995. Jos: Institute of governance and Social Research. 194-211.

[21] Oyewo, A. (1983). The Administration and Management of Ibadan Municipal Government 1954-1979, M. Phil Thesis. The University of Ife, Unpublished.

[22] Popoola, A. A. and Magidimisha H. H. (2020). The Dilemmas of Rural Planning and Planners in Oyo State, Nigeria. Bulletin of Geography. Socio-economic Series, 47 (47): 75-93. DOI: http://doi.org/10.2478/bog-2020-0005.

[23] Sokoh, G. C. (2018). A Historical Analysis of the Changing Role of Traditional Rulers in Governance in Nigeria. Journal of Humanities and Social Science, 23 (1), 51-62.

[24] Tonwe, D., A., and Osemwota (20130. Traditional Rulers and Local Governance in Nigeria: a Pathway to Resolving the Challenges. Commonwealth Journal of Local Governance, 13 (14), 128-140.

[25] Vansina, J. (1962). A Comparison of African Kingdoms. Africa: Journal of the International African Institute, Vol. 32 (4), pp. 324-335.

[26] Yahaya, A. D Alemika, E. O., Amucheazi, E., Oyebode, A. B. and Yahaya, A. D., 2010, Traditional Rulers in Nigeria, Ibadan: Safari Books. 